Research Article

\title{
Physiological traits of the symbiotic bacterium Teredinibacter turnerae isolated from the mangrove shipworm Neoteredo reynei
}

\author{
Amaro E. Trindade-Silva, Erik Machado-Ferreira, Marcus V.X. Senra, Vinicius F. Vizzoni, \\ Luciana A. Yparraguirre, Orilio Leoncini and Carlos A.G. Soares \\ Laboratório de Genética Molecular de Eucariontes e Simbiontes, Departamento de Genética, \\ Instituto de Biologia, Universidade Federal do Rio de Janeiro, Rio de Janeiro, RJ, Brazil.
}

\begin{abstract}
Nutrition in the Teredinidae family of wood-boring mollusks is sustained by cellulolytic/nitrogen fixing symbiotic bacteria of the Teredinibacter clade. The mangrove Teredinidae Neoteredo reynei is popularly used in the treatment of infectious diseases in the north of Brazil. In the present work, the symbionts of $N$. reynei, which are strictly confined to the host's gills, were conclusively identified as Teredinibacter turnerae. Symbiont variants obtained in vitro were able to grow using casein as the sole carbon/nitrogen source and under reduced concentrations of $\mathrm{NaCl}$. Furthermore, cellulose consumption in $T$. turnerae was clearly reduced under low salt concentrations. As a point of interest, we hereby report first hand that $T$. turnerae in fact exerts antibiotic activity. Furthermore, this activity was also affected by $\mathrm{NaCl}$ concentration. Finally, T. turnerae was able to inhibit the growth of Gram-negative and Gram-positive bacteria, this including strains of Sphingomonas sp., Stenotrophomonas maltophilia, Bacillus cereus and Staphylococcus sciuri. Our findings introduce new points of view on the ecology of $T$. turnerae, and suggest new biotechnological applications for this marine bacterium.
\end{abstract}

Key words: Teredinibacter turnerae, cellulolytic and nitrogen fixing bacteria, antibiotic activity, mangrove shipworm symbiont, Neoteredo reynei.

Received: October 16, 2008; Accepted: March 23, 2009.

\section{Introduction}

The family Teredinidae is composed of obligate marine woodboring mollusks of wide geographical distribution (Turner, 1966). Nutrition in shipworms is supported by symbiotic association with the cellulolytic/nitrogen fixing bacterium Teredinibacter turnerae (Carpenter and Culliney, 1975; Trytek and Allen, 1980; Gallager et al., 1981; Waterbury et al., 1983; Distel et al., 2002b; Lechene et al., 2007). T. turnerae is a Gram-negative marine bacterium, requiring $0.3 \mathrm{M} \mathrm{NaCl}$ and other salts for optimum growth. Furthermore, this symbiont can use cellulose as the sole carbon source and fix dinitrogen under micro-aerobic conditions. It also requires combined nitrogen in a vigorously aerated culture (Distel et al., 2002b). T. turnerae is located in symbio in the shipworm's gills, within specialized structures comprised of bacteriocytes, the so called glands of Deshayes (Distel et al., 2002a; Distel, 2003; Lechene et al., 2007). This bacterium is thought to be the sole symbiont in all the Teredinidae family (Waterbury et al., 1983; Distel et al., 1991, 2002b). In addition, closely related symbiont

Send correspondence to Carlos A.G. Soares. Departamento de Genética, Instituto de Biologia, Universidade Federal do Rio de Janeiro, CCS, Bloco A, Lab. A2-120, 21944-970 Rio de Janeiro, RJ, Brazil. E -mail: soares@ biologia.ufrj.br. ribotypes within the Teredinibacter clade have been described as co-existing inside one sole gill tissue (Distel et al., 2002a; Luyten et al., 2006). T. turnerae is the only known bivalve-gill endosymbiont that can be cultured (Sipe et al., 2000; Distel et al., 2002b), and has been shown to present a potential for biotechnological application (Greene and Freer, 1986; Greene et al., 1988, 1989; Griffin et al., 1992; Ahuja et al., 2004; Lim and Haygood, 2004; Xu and Distel, 2004).

A specific Teredinibacter symbiont ribotype was characterized as colonizing the gills and gonads of Bankia setacea, a large shipworm found in temperate waters (Sipe et al., 2000). In tropical estuaries the Teredinidae Neoteredo reynei infests mangrove wood. Besides being the only species of the genus, it is one of the largest members in the family, reaching 1.5 meters in length (Turner, 1966). In the northern coast of Brazil, this shipworm is locally known as "Turu" and it is popularly used for the treatment of certain infectious diseases, as well as for enhancing food supplements (Andrade, 1979). Other marine invertebrates are the source of bioactive compounds, which in many cases were found to be produced by associated bacteria (Piel, 2004). These findings reinforce the need for understanding bacteria/Teredinidae host interactions. 
Two pertinent facts are that the gland of Deshayes has been observed in N. reynei (DeMoraes and Lopes, 2003) and that cellulolytic/nitrogen fixing bacteria have already been isolated from the gills thereof (Distel et al., 2002b). Nevertheless, the identity of this mangrove shipworm symbiont has not as yet been confirmed by molecular tools. In the present work $N$. reynei symbionts were isolated and characterized, T. turnerae antibacterial activity described for the first time, and bacterial variants with new distinctly physiological traits obtained in vitro. Aspects of these traits in T. turnerae ecology are discussed, our findings suggesting new biotechnological applications for this marine bacterium.

\section{Materials and Methods}

\section{Specimens}

Adult $N$. reynei were collected at the Coroa Grande mangrove area in Sepetiba Bay (Rio de Janeiro, Brazil). Animals collected from decaying wood were immediately transported to the laboratory in autoclaved vials and aseptically dissected. The gills, gonads, intestines and siphons were individually washed and processed for the isolation of symbiotic bacteria and/or extraction of total DNA and RNA.

\section{Symbiont purification and culture}

Freshly dissected $N$. reynei gills were individually washed five times in $1 \mathrm{~mL}$ of a sterile sea water/distilled water 3:1 solution (SWS) and then homogenized in $500 \mu \mathrm{L}$ of SWS. Serial dilutions were inoculated in $1 \mathrm{~cm}$ diameter tubes containing $2 \mathrm{~mL}$ of a semi-solid Shipworm Basal Medium (SBM), supplemented with $0.2 \%(\mathrm{w} / \mathrm{v})$ agar and $0.5 \%$ $(\mathrm{w} / \mathrm{v})$ powdered cellulose (Sigmacell 101), but without combined nitrogen, so as to select nitrogen fixing bacteria under proper microaerophilic conditions, as previously described (Waterbury et al., 1983). Tubes were incubated at $30{ }^{\circ} \mathrm{C}$ and individual colonies obtained, after streaking the pellicle growth from the highest dilution growth $\left(10^{-4}-10^{-7}\right)$ on $1 \%(\mathrm{w} / \mathrm{v})$ agar SBM plates supplemented with $0.5 \%$ (w/v) Sigmacell 101 and $0.1 \%(w / v) \mathrm{NH}_{4} \mathrm{Cl}$. Purified bacterial cultures were confirmed for cellulose utilization and growth in semi-solid SBM tubes without combined nitrogen. Purified bacteria were plated onto a Basal Medium (BM) (Greene and Freer, 1986) (modified by A.R. Moreira, unpublished data), with the addition of $0.1 \%(\mathrm{w} / \mathrm{v}) \mathrm{NH}_{4} \mathrm{Cl}$, $0.3 \mathrm{M} \mathrm{NaCl}$ and $0.5 \%(\mathrm{w} / \mathrm{v})$ cellulose (Sigmacell 101) (BMC) or $0.5 \%$ (w/v) sucrose (BMS), as specified. Modified $\mathrm{BM}$ contained: $\mathrm{KCl}, 5.36 \mathrm{mM} ; \mathrm{MgSO}_{4} .7 \mathrm{H}_{2} \mathrm{O}$, $7.7 \mathrm{mM} ; \mathrm{MgCl}_{2} .6 \mathrm{H}_{2} \mathrm{O}, 7.38 \mathrm{mM} ; \mathrm{CaCl}_{2} .2 \mathrm{H}_{2} \mathrm{O}, 2.72 \mathrm{mM}$; HEPES (N-[2-hydroxyethyl]piperazine-N'-[2-ethanesulfonic acid]), $20.5 \mathrm{mM}$; Solution A, $10 \mathrm{~mL}$; and a trace metal solution, $1 \mathrm{~mL}$; the medium was set to $\mathrm{pH}$ 8.0. Solution A consisted of: $\mathrm{K}_{2} \mathrm{HPO}_{4} .3 \mathrm{H}_{2} \mathrm{O}, 0.1 \mathrm{M} ; \mathrm{Na}_{2} \mathrm{CO}_{3}, 0.11 \mathrm{M}$; and $\mathrm{Fe}_{2}\left(\mathrm{SO}_{4}\right)_{3}, 0.75 \mathrm{mM}$. The trace metal solution contained:
$\mathrm{H}_{3} \mathrm{BO}_{3}, 46.9 \mathrm{mM} ; \mathrm{MnCl}_{2} .4 \mathrm{H}_{2} \mathrm{O}, 0.11 \mathrm{M} ; \mathrm{ZnSO}_{4} .7 \mathrm{H}_{2} \mathrm{O}$, $0.70 \mathrm{mM} ; \mathrm{Na}_{2} \mathrm{MoO}_{4} .2 \mathrm{H}_{2} \mathrm{O}, 0.16 \mathrm{mM} ; \mathrm{CoSO}_{4} .7 \mathrm{H}_{2} \mathrm{O}$, $0.18 \mathrm{mM}$; and $\mathrm{CuSO}_{4} .5 \mathrm{H}_{2} \mathrm{O}, 0.32 \mathrm{mM}$. All solid media included $1 \%(\mathrm{w} / \mathrm{v})$ agar. All T. turnerae were grown at $30^{\circ} \mathrm{C}$ and cultures stored in liquid BMS at $-80^{\circ} \mathrm{C}$, after the addition of $25 \%(\mathrm{v} / \mathrm{v})$ glycerol.

\section{Selecting T. turnerae variants}

A selective growth condition was designed to spontaneously obtain $T$. turnerae variants capable of growing under low-salt concentration conditions, and of using casein as the sole carbon and combined nitrogen source, as previously observed (Ferreira et al., 2001). T. turnerae was challenged to grow on a usually non-permissive growth medium with low salt content, by streaking a pure culture of T. turnerae CS30 on plates containing a NaCl-free BM sucrose medium $\left(\mathrm{BMS}^{\mathrm{Ls}}\right.$, Low salt) overlaid with $5 \%(\mathrm{w} / \mathrm{v})$ casein in a BM with (BM5Ca) or without $\left(\mathrm{BM}_{5} \mathrm{Ca}^{\mathrm{Ls}}\right) \mathrm{NaCl}$, following 5-10 days incubation at $30{ }^{\circ} \mathrm{C}$. Each CS30 streak with positive growth was purified on $\mathrm{BM}$ media with $0.5 \%$ $(\mathrm{w} / \mathrm{v})$ casein and $0.3 \mathrm{M} \mathrm{NaCl}(\mathrm{BMCa})$. Distinct from original $T$. turnerae isolates, the new bacterial cultures were then able to grow in a low salt medium $(\mathrm{NaCl}$ free), by using either casein $\left(\mathrm{BMCa}^{\mathrm{Ls}}\right.$, Low salt medium) or sucrose $\left(\mathrm{BMS}^{\mathrm{Ls}}\right.$, Low salt medium) as the carbon source. $\mathrm{No} \mathrm{NH}_{4} \mathrm{Cl}$ was added to casein-containing media.

\section{Nucleic acids extraction}

Freshly dissected $N$. reynei tissues were washed five times in $1 \mathrm{~mL}$ TE pH 8.0 and then snap-frozen in liquid nitrogen. Up to $500 \mu \mathrm{L}$ of each $N$. reynei tissue homogenate were mixed with $500 \mu \mathrm{L}$ of $5 \%$ (w/v) sucrose, $100 \mathrm{mM}$ Tris $\mathrm{pH} 7.5,600 \mathrm{mM} \mathrm{NaCl}, 100 \mathrm{mM}$ EDTA and a $1 \%(\mathrm{w} / \mathrm{v})$ sodium dodecyl sulfate (SDS) solution, and incubated for $30 \mathrm{~min}$ at $60{ }^{\circ} \mathrm{C}$. After Proteinase $\mathrm{K}\left(0.4 \mathrm{mg} \mathrm{mL}{ }^{-1}\right)$ and

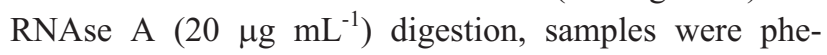
nol/chloroform extracted and bulk DNA precipitated, washed with isopropanol/ethanol, and then dried and resuspended in $50 \mu \mathrm{L}$ of sterile ultra-pure water.

T. turnerae total DNA was extracted from cell pellets of 0.5-1 mL of 2-days growth in liquid BMS. Bacterial cells were resuspended in $0.5 \mathrm{~mL}$ of $50 \mathrm{mM}$ Tris- $\mathrm{HCl} \mathrm{pH} 8.0$ and a $50 \mathrm{mM}$ EDTA solution, and frozen at $-20^{\circ} \mathrm{C}$. Frozen cells were incubated at room temperature for lysozyme $\left(1 \mathrm{mg} \mathrm{mL}{ }^{-1}\right)$ digestion. After incubation with $100 \mu \mathrm{L}$ of $1 \mathrm{mg} \mathrm{mL}^{-1}$ Proteinase $\mathrm{K}$ in $50 \mathrm{mM}$ Tris, $0.4 \mathrm{M}$ EDTA, a $0.5 \%(\mathrm{w} / \mathrm{v}) \mathrm{SDS}$ solution and $20 \mu \mathrm{g}$ of RNAse A for $20 \mathrm{~min}$ at $50{ }^{\circ} \mathrm{C}$ (Silhavy et al., 1984), samples were phenol/chloroform extracted. The DNA was precipitated, washed, dried and resuspended in $50 \mu \mathrm{L}$ of sterile ultra-pure water.

Total RNA was extracted from either $N$. reynei gill tissues or bacterial cell pellets from $1 \mathrm{~mL}$ of specific $T$. turnerae growth. The RNeasy Protect Mini Kit (Qiagen, Valencia, CA) was used according to manufacturer's 
recommendations. Snap-frozen gills were homogenized with $100 \mu \mathrm{L}$ of RNAlater solution (Qiagen, Valencia, CA) and added to $500 \mu \mathrm{L}$ of a lysis buffer (RNeasy kit, Qiagen). Recovered bulk RNA was stored at $-80^{\circ} \mathrm{C}$.

\section{S rRNA gene analysis}

$N$. reynei tissues and bacterial total DNA were used as templates for 16S rRNA gene (16S rDNA) PCR amplification. Eubacterial specific primers $27 \mathrm{f}$ and $1492 \mathrm{r}$ were used (Lane, 1991). The purified $1.4 \mathrm{kbp}$ PCR products were individually digested with HaeIII, AluI and separated in $8 \%$ non-denaturing polyacrylamide gels. These enzymes were verified as discriminative for many Teredinidae symbiont ribotypes available in GenBank (accession numbers AY028398, AF102866, AY150183, AY150184, AY150578 and DQ272300 to DQ272317). In addition, four different PCR reactions with the same DNA template were combined and the purified 16S rDNA PCR products (150-500 ng) sequenced, by using the DYEnamic ET Dye Terminator Cycle Sequencing Kit (Amersham Biosciences, Piscataway, NJ) and the specific eubacterial $16 \mathrm{~S}$ rRNA primers 27f, 1492r, 338f, 338r, 907f, 907r, $1100 \mathrm{f}$ and 1100r (Lane, 1991). Sequences were edited by using the SeqMan program (DNASTARinc package for Windows platform, 1989-1999), and analyzed for identity matching with BlastN.

\section{celA analyses and T. turnerae PCR screening}

Screening for T. turnerae in distinct shipworm tissues was performed by PCR with primers specific for the Teredinidae Psiloteredo healdi symbiont celA cellulase gene (Freer et al., 2001). The primer set PcelA-f (5'CTGTATCG GCCGAACCACCTG3') and PcelA-r (5'TTGCGTTCC AGTCGTCTTTCA3') was synthesized to amplify the bases 661-1897 of the celA locus, this including the putative celA promoter region (Freer et al., 2001). The primers celA-f (5'CACCCAGGGCAACACTCAACC3') and celA-r (5'GGCGCGGCTTATGGGATTGAC3') amplified the region 1592-4732 including the entire celA ORF. PCR controls were performed with the primer set EukA/EukB for the termini of the eukaryotic 18S rRNA (Medlin et al., 1988; Sipe et al., 2000).

$N$. reynei tissues and T. turnerae total RNAs were used as templates for celA RT-PCR reactions by means of the SuperScript III One Step RT-PCR System with Platinum ${ }^{\circledR}$ Taq DNA Polymerase (Invitrogen, Carlsbad, CA) and the primer set celA-f/PcelA-r.

\section{Carboxymethylcellulose (CMC) digestion test}

T. turnerae grown on BMS plates (two days at $30^{\circ} \mathrm{C}$ ) were streaked onto fresh BMS plates overlaid with $1 \%$ $(\mathrm{w} / \mathrm{v})$ agar plus $0.1 \%(\mathrm{w} / \mathrm{v}) \mathrm{CMC}$, and incubated for two days at $30{ }^{\circ} \mathrm{C}$. Plates were stained with $1 \mathrm{mg} \mathrm{mL}^{-1}$ Congored at room temperature for $15 \mathrm{~min}$ and then washed with
$1 \mathrm{M} \mathrm{NaCl}$ for visualization of CMC digestion (Teather and Wood, 1982).

\section{T. turnerae growth kinetics}

T. turnerae clumps when cultured in liquid medium, thus impairing proper colony counts by regular plating methodology. Therefore, bacterial growth in liquid media $\left(\mathrm{BMC}, \mathrm{BMC}^{\mathrm{Ls}}\right.$, BMCa or $\mathrm{BMCa}^{\mathrm{Ls}}$ ) was quantified by determining the total DNA concentration in the cultures. All pre-inocula were obtained by thoroughly resuspending a loopful of a two days BMS plate growth of the bacterial variant in $28 \mathrm{~mL}$ of fresh BMS. Initially, this mix was split into $2 \mathrm{~mL}$ aliquots. After two days of growth at $30^{\circ} \mathrm{C}$ under $115 \mathrm{rpm}$, two tubes were used to determine DNA concentration, thereby yielding the "time zero" point determination for the kinetics curves. The entire cell content of the remaining tubes was individually pelleted $(9,200 \mathrm{~g}$ for $2 \mathrm{~min}$ ) and used as a pre-inoculum for a fresh $25 \mathrm{~mL}$ of the specific tested medium (BMC, $\mathrm{BMC}^{\mathrm{Ls}}, \mathrm{BMCa}$ or $\mathrm{BMCa}^{\mathrm{Ls}}$ ) in $125 \mathrm{~mL}$ erlenmeyers. These cultures were incubated at $30{ }^{\circ} \mathrm{C}$, under $115 \mathrm{rpm}$, in order to generate duplicated three time-point growths for both $\mathrm{NaCl}$-free and $\mathrm{NaCl}$ added conditions. Individual growth flasks were used for each time-point at two, four and eight days of incubation. All assays were performed twice to six times for each time-point and the DNA concentration determined in triplicate for each sample.

Total DNA concentration in each culture was quantified by pelleting the cell content, centrifuging the total volume of the culture at 9,200 $\mathrm{g}$ for $2 \mathrm{~min}$, and then washing any adhered cell biofilm with SWS. The cell pellet was resuspended in $5 \mathrm{~mL}$ of $50 \mathrm{mM}$ Tris- $\mathrm{HCl} \mathrm{pH} 8.0,50 \mathrm{mM}$ EDTA solution, and then frozen at $-20{ }^{\circ} \mathrm{C}$. Frozen cells were kept at room temperature with $100 \mu \mathrm{L}$ of $10 \mathrm{mg} \mathrm{mL}^{-1}$ lysozyme in $0.25 \mathrm{mM}$ Tris $\mathrm{pH} 8.0$ until melted, and were then kept on ice for 45 min. Proteinase $\mathrm{K}$ was added [500 $\mu \mathrm{L}$ of a $1 \mathrm{mg} \mathrm{mL}^{-1}$ solution in $50 \mathrm{mM}$ Tris, $0.4 \mathrm{M}$ EDTA, $0.5 \%(\mathrm{w} / \mathrm{v}) \mathrm{SDS}$ ] and incubated for $20 \mathrm{~min}$ at $50^{\circ} \mathrm{C}$. For each culture cell lysate, three $500 \mu \mathrm{L}$ samples were collected for total DNA purification. RNAse A was added $\left(20 \mu \mathrm{g} \mathrm{mL}^{-1}\right)$ and the extraction processed as described above. Purified DNA was resuspended in $500 \mu \mathrm{L}$ of ultra pure-water and quantified by $\mathrm{A}_{260 \mathrm{~nm}}$ readings. DNA concentrations are shown as $\mu \mathrm{g}$ DNA mL ${ }^{-1}$ of the culture. Differences in the mean number of the log of bacterial DNA concentration in the media were determined by the Student $t$-test, with a $p$ value $<0.05$ being considered statistically significant.

\section{Assessment of $T$. turnerae antimicrobial activity}

Plating tests to detect T. turnerae antibacterial activity were undertaken by streaking the original symbiont strain CS30 (see Results for details) on plates of LuriaBertani (LB) media overlaid with BMS top-agar inoculated 
with bacterial suspensions. A similar top-agar on Sabouraud plates was used for tests of yeast growth inhibition (Kreger-van Rij, 1984). Distinct Gram-negative bacteria families were tested, including E. coli $\mathrm{DH} 5 \alpha$, Vibrio harveyi BB120 (Surette and Bassler, 1998), Pseudomonas putida (ATCC 15175), P. fluorescens (ATCC 13525), Chromobacterium violaceum CV026 (Throup et al., 1995), Sphingomonas sp. CS81, environmental strains of Serratia marcescens CS265, Stenotrophomonas maltophilia CS266 and the Gram-positive environmental strains of Bacillus cereus CS262 and Staphylococcus sciuri BB20-06. Sphingomonas sp. CS81 is closely related to Sphin. panni (Busse et al., 2005), and was obtained as a pinkish laboratory contaminant in BMS media, its identity being confirmed by $16 \mathrm{~S}$ rRNA gene sequencing (GenBank EU684539). All the environmental strains were previously isolated in our lab from tick samples and had their identity confirmed by 16S rRNA gene analyses as indicated (GenBank EU693533, EU693532, EU693531 and EU693530, respectively). The yeasts Saccharomyces cerevisiae NRRL Y-12632 (ARS Culture Collection NRRL, USDA) and Candida albicans NRRL Y-12983 (ARS Culture Collection NRRL, USDA) were also tested. Tested bacteria were initially grown overnight on LB agar. Only Sphingomonas sp. CS81 was grown on BMS and tested on both BMS and LB BMS top-agar. Yeasts were grown on Sabouraud agar. All inocula testing was done by individually resuspending a loop-full of each microorganism growth in $4 \mathrm{~mL}$ of BMS top-agar.

Crude methanolic extracts of 3-day-old liquid cultures of CS30 in BMS were also tested for antibiotic activity. T. turnerae was grown in $100 \mathrm{~mL}$ of a liquid medium, the whole culture content then being lyophilized and resuspended in $10 \mathrm{~mL}$ of methanol. After filtration of insoluble debris, the extracts were dried by vacuum centrifugation and finally resuspended in $1 \mathrm{~mL}$ of methanol. Sterile filter-paper discs soaked with $5 \mu \mathrm{L}$ of these crude methanolic extracts were air-dried and layed onto plates inoculated with the target bacteria on top-agar. Test plates were incubated for 1-7 days until inhibition-halo detection. All growths were performed at $30^{\circ} \mathrm{C}$, so that all microorganisms were able to grow under the tested conditions.

\section{Results}

\section{Isolation and molecular characterization of $N$. reynei symbionts}

Bacteria were isolated from the gills of $N$. reynei after selection in cellulose/combined nitrogen-free semi solid SBM medium. Eighteen pure morphologically identical cultures were obtained. The isolates denominated CS30, CS32, CS37 and CS41 were purified from distinct $N$. reynei individuals and randomly selected for further analysis. These bacteria were able to grow in regular BMC or BMS media. 16S rDNA analysis was performed by using each bacterial isolate and $N$. reynei gills bulk DNA. 16S rDNA $1.4 \mathrm{kbp}$ PCR amplicons were individually digested with HaeIII and AluI (Figure 1). All isolates and the 16S rDNA directly amplified from $N$. reynei gills showed an identical HaeIII digestion pattern. Only $16 \mathrm{~S}$ rDNA of CS32 presented a distinct $A l u \mathrm{I}$ digestion profile. The HaeIII and AluI patterns observed for CS30, CS37 and CS41 16S rDNAs were identical to those expected for the T. turnerae T7902 type strain (GenBank AY028398), thereby indicating that
A)

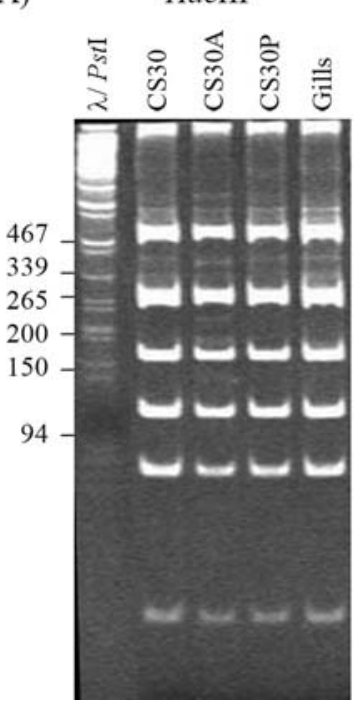

Alul

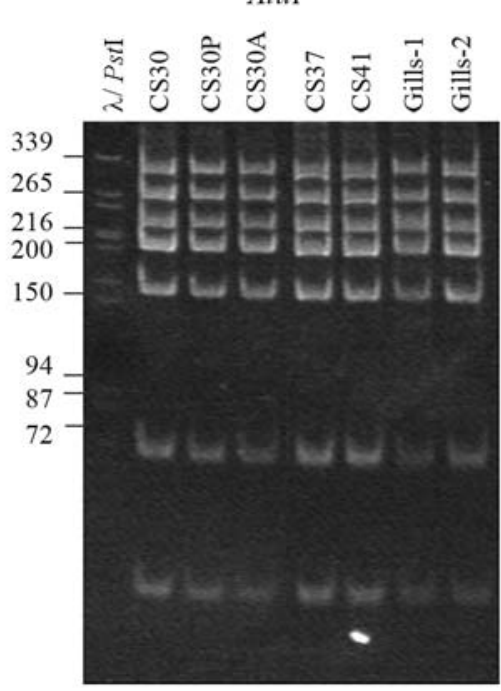

B) HaeIII

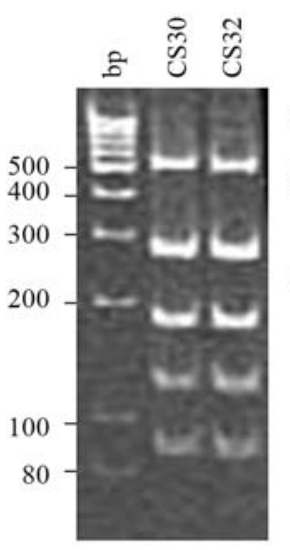

Alul

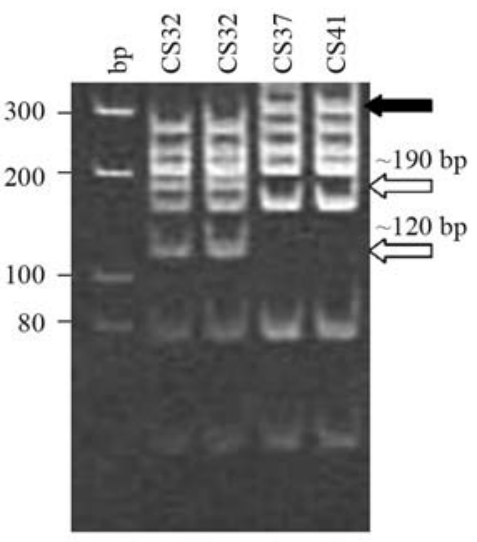

Figure 1 - HaeIII and AluI digestion patterns of 16S rDNA PCR products amplified from cellulolytic/nitrogen fixing bacteria isolates and $N$. reynei gills. (A) Digestion profiles for the T. turnerae CS30, CS37, CS41 isolates, gill-bulk DNA amplicons and CS30A and CS30P variants. (B) Distinction of the $T$. turnerae CS32 isolate16S rDNA digestion pattern from CS30, CS37 and CS41 isolates. *DNA markers are shown in base pairs. **Absent and emerging bands in the CS32 profile are indicated by black and white arrows, respectively. ***See Materials and Methods for details. 
in N. reynei the bacterium T. turnerae is found as a symbiont, as it is in many other Teredinidae. In fact, the $16 \mathrm{~S}$ rDNA $1.4 \mathrm{kbp}$ PCR product of both CS30 (chosen as a representative of the $N$. reynei symbiotic consortia) and CS32 was sequenced (GenBank AY949835 and AY949836, respectively). These sequences shared $99 \%$ identity with the T. turnerae type strain 16S rRNA sequence, thus confirming their being T. turnerae. The CS32 16S rDNA sequence presented one additional $\mathrm{T}-\mathrm{G}$ transversion at position $456 \mathrm{bp}$, thereby creating an extra $A l u \mathrm{I}$ restriction site and generating the unique $A l u \mathrm{I}$ pattern (Figure 1B).

The 16S rDNA PCR products from CS37, CS41 and from the bulk DNA of $N$. reynei gills were also partially sequenced by using the primers $27 \mathrm{f}, 338 \mathrm{r}$ and $907 \mathrm{r}$. These primers flank the variable portions $\mathrm{V} 1, \mathrm{~V} 2$ and $\mathrm{V} 3$ of the 16S rRNA (Neefs et al., 1993; Van de Peer et al., 1996a, 1996b), and together can discriminate 16S rRNA sequences from shipworm symbiont ribotypes deposited in GenBank (Sipe et al., 2000; Distel et al., 2002a, 2002b; Luyten et al., 2006) (data not shown). Partial sequences from all the samples attributed the highest identity to the $T$. turnerae type strain $16 \mathrm{~S}$ rRNA.

\section{Molecular screening for $T$. turnerae in distinct host tissues}

PCR strategy was used to determine T. turnerae distribution in $N$. reynei tissues. Primers to the multidomain cellulase celA gene were designed and the presence of celA in CS30 was confirmed by both PCR and sequence analysis. A $\sim 4 \mathrm{kbp}$ amplicon, including the entire $\mathrm{cel} A$ gene and its promoter region, was amplified with the PcelA-f/celA-r primer set. NESTED-PCRs, together with the internal primer sets PcelA-f/PcelA-r for the putative celA promoter, celA-f/celA-r for the whole celA coding sequence and celA-f/PcelA-r, amplified the $1236 \mathrm{bp}, 3140 \mathrm{bp}$ and $305 \mathrm{bp}$ products, respectively. These represented the expected amplicons for the described celA locus (Freer et al., 2001). Partial sequencing of the $3140 \mathrm{bp}$ fragment confirmed it as a $N$. reynei symbiont celA gene version (data not shown). Positive RT-PCR amplification showed that celA was being expressed in CS30, and reactions using $N$. reynei gillbulk RNA indicated this was also so in symbio (Figure 2A).

DNA extracts from $N$. reynei gills, gonads, mantle (not shown), siphons and intestine were initially screened for the presence of eubacterial 16S rDNA (Figure 2B). PCR reactions with samples of the gills and intestines generated the expected amplicons, and so were subjected to a specific PCR screening for $T$. turnerae by using putative celA promoter primers (Figure 2C). Only the gills produced the expected celA band, thereby indicating that the T. turnerae symbiont is restricted to this tissue, whereas other eubacteria are present in shipworm intestines. Reactions with gonad, mantle and siphon samples were negative for celA (data not shown) and positive for the 18S rDNA controls (Figure 2D).

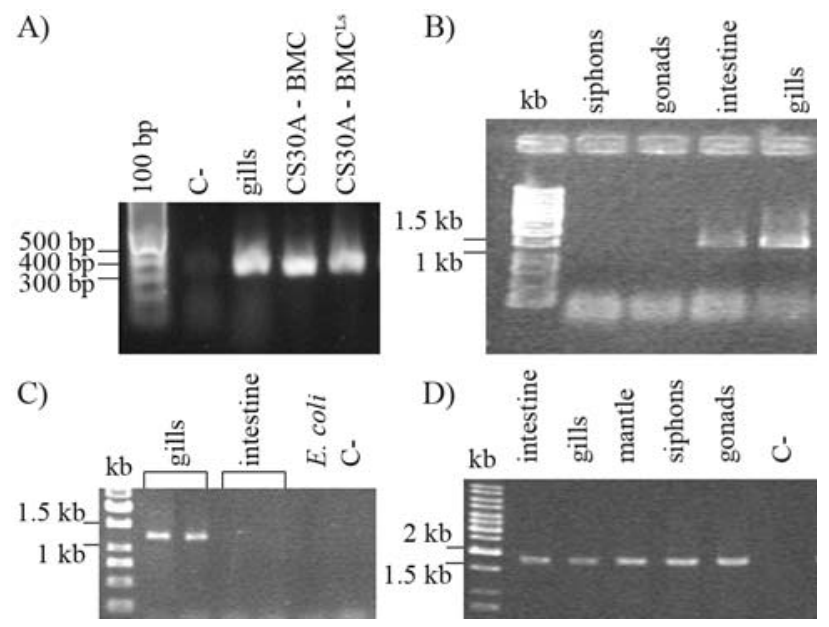

Figure 2 - celA gene and eubacterial 16S rDNA amplifications from $T$. turnerae and N. reynei tissue samples. (A) RT-PCR assessment of celA expression in the gills and by T. turnerae CS30A growing in cellulose media with $0.3 \mathrm{M} \mathrm{NaCl}(\mathrm{BMC})$ or under low salt concentration $\left(\mathrm{BMC}^{\mathrm{Ls}}\right)$. Reactions using the primer set celA-f and PcelA-r. (B) PCR for eubacterial 16S rDNA in $N$. reynei tissues. (C) PCR for the T. turnerae celA promoter region in $N$. reynei tissues containing eubacteria. (D) PCR amplification of eukaryotic $18 \mathrm{~S}$ rDNA in $N$. reynei tissue samples.

\section{T. turnerae spontaneous variants}

T. turnerae is described as a restricted marine bacterium (Distel et al., 2002b), and despite secreting protease(s), it cannot grow by using casein as the sole carbon and nitrogen source (Greene et al., 1989; Griffin et al., 1992). It was also reported to be highly polymorphic (Waterbury et al., 1983; Ferreira et al., 2001; Distel et al., 2002b), and could potentially lead to new emerging physiological traits in this biotechnologically relevant bacterium. In fact, Ferreira et al. (2001) reported new physiological traits in a $T$. turnerae variant spontaneously obtained in vitro, which appeared as an "aggregate form" with a distinct exopolysaccharide content, and as also having acquired the ability to use casein without the addition of $\mathrm{NaCl}$. However, this unidentified variant was incapable of consuming cellulose. Based on this knowledge, a selective condition was designed to test the ability to select variants from the $N$. reynei symbiont CS30. Two spontaneous $T$. turnerae variants were successfully obtained after selection in a low saltcontent medium with casein (Materials and Methods). Purified cultures were obtained from those few CS30 streaks with positive growth. One variant presented a yellow color on BM5Ca top agar and was denoted CS30A. The other variant, manifesting intense protease activity and with an evident casein degradation halo on the $\mathrm{BM} 5 \mathrm{Ca}^{\mathrm{Ls}}$ top agar, was named CS30P. The identity of CS30A and CS30P as $T$. turnerae, besides the absence of any other bacterial type, were confirmed by HaeIII and AluI 16S rDNA PCR-RFLP (Figure 1A) and partial sequencing of a $\sim 800 \mathrm{bp} \mathrm{PCR}$ amplicon including the $\mathrm{V} 1$ and $\mathrm{V} 216 \mathrm{~S}$ rDNA regions (data not shown). 
CS30A and CS30P were still capable of using cellulose and manifest pellicle growth in the combined nitrogen-free/microaerobic conditions of a semi-solid SBM medium. These cultures preserved the same growth ability of the original CS30 isolate, this including cellulase secretion on BMS, as defined by CMC degradation tests (data not shown). However, they had acquired novel physiological traits (Table 1). Plate tests on BMC and BMCa agar, with and without the addition of $0.3 \mathrm{M} \mathrm{NaCl}$, demonstrated that CS30A and CS30P presented vigorous growth when using casein as the sole carbon and nitrogen source, independent of the addition of $\mathrm{NaCl}$. These bacteria were also capable of using cellulose in the absence of $\mathrm{NaCl}$, although T. turnerae growth was notably reduced on cellulose agar under these conditions. This specific capacity for growth in these variants was clearly stable, even after having remained for months in SBM. Notably, a direct inoculum of CS30 was incapable of growing either in casein or low-salt medium.

Growth kinetics in CS30, CS30A and CS30P is very similar when using cellulose with $0.3 \mathrm{M} \mathrm{NaCl}$, as determined by total DNA concentration in the cultures (Figure $3 \mathrm{~A}$ ). On the other hand, growth kinetics in CS30A and CS30P was similar when using casein or cellulose in a low-salt medium. A more intense growth was observed during the first two days, reaching maximum counts after four days. Although still able to grow under low $\left[\mathrm{Na}^{+} \mathrm{Cl}^{-}\right]$ conditions, $T$. turnerae variants were clearly constrained thereat. This effect was more pronounced when cellulose was used as the sole carbon source, whereby the low-salt concentration caused a notable drop in $T$. turnerae growth $(\mathrm{p}<0.05)$ (Figures 3A-3B). Interestingly, T. turnerae still maintained celA gene transcription, even when grown under these conditions (Figure 2A).

\section{T. turnerae displays antibacterial activity}

In order to verify those antimicrobial activities of $N$. reynei symbionts that could potentially be related to its use as a therapeutic, natural-product, direct plating tests were undertaken by growing CS30 on BMS top-agar containing a variety of Gram-negative and Gram-positive bacteria, as well as yeasts. Inhibitory activity could be detected against the Gram-negative strains of Sphingomonas sp., Sten. maltophilia and the Gram-positive B. cereus and Staph. sciuri (Table 1, Figure 4). The same result was observed when CS30 crude methanolic extracts were used instead of live bacteria. Direct plating of the T. turnerae variants CS30A and CS30P also caused intense inhibition of Sphingomonas sp. but had no evident effect on Sten. maltophilia, B. cereus or Staph. sciuri cultures (Table 1). All this indicates that $T$. turnerae potentially secretes various compounds, thereby distinctly inhibiting the growth of Sphingomonas and other bacteria. Interestingly, when CS30A or CS30P were tested on the low-salt medium $\mathrm{BMS}^{\mathrm{Ls}}$, the inhibition of Sphingomonas was no longer observed, this indicating that $\mathrm{NaCl}$ is required for the production, activity and/or sensitivity of Sphingomonas to $T$. turnerae bioactive compounds. A distinct and opposite activity of $T$. turnerae growths and extracts was also detected. This activity was characterized by growth enhancement of tested bacteria observed just beyond the inhibition zone (Figure 4). This growth enhancing activity was investigated no further. In conjunction these data present a new potential application of T. turnerae as a bioactive compound producer.

\section{Discussion}

The Teredinidae and their bacterial symbiont $T$. turnerae have attracted interest due to their economic relevance and by offering a unique system for nitrogen fixing bacteria/animal host interaction studies. $N$. reynei is particularly conspicuous through being the biggest member of the Teredinidae family, its role in mangrove ecology and its therapeutic use on the northern coast of Brazil. In the present work, we isolated, characterized and identified $T$. turnerae as its symbiotic bacteria. Two distinct T. turnerae strains, represented by the CS30 and CS32 isolates, were found by $16 \mathrm{~S}$ rDNA analysis of cellulolytic/nitrogen fixing

Table 1 - T. turnerae variants growth and antibiotic activity profile.

\begin{tabular}{|c|c|c|c|c|c|c|c|c|}
\hline \multirow[t]{3}{*}{ T. turnerae variant } & \multicolumn{4}{|c|}{ Growth profile* } & \multicolumn{4}{|c|}{ Antibiotic activity $^{\dagger}$} \\
\hline & \multicolumn{2}{|c|}{$\mathrm{BM}(0.3 \mathrm{M} \mathrm{NaCl})$} & \multicolumn{2}{|c|}{$\mathrm{BM}^{\mathrm{Ls}}$ (low salt) } & \multirow[b]{2}{*}{ Sphingomonas sp. } & \multirow[b]{2}{*}{ Sten. maltophilia } & \multirow[b]{2}{*}{ B. cereus } & \multirow[b]{2}{*}{ Staph. sciuri } \\
\hline & Cellulose & Casein & Cellulose & Casein & & & & \\
\hline CS30 & + & - & - & - & + & + & + & + \\
\hline $\mathrm{CS} 30 \mathrm{~A}$ & + & + & \pm & + & + & - & - & - \\
\hline $\mathrm{CS} 30 \mathrm{P}$ & + & + & \pm & + & + & - & - & - \\
\hline
\end{tabular}

*Four days growth on $\mathrm{BM}$ or $\mathrm{BM}{ }^{\mathrm{Ls}} \mathrm{NaCl}$-free solid media at $30^{\circ} \mathrm{C}$. “+” = positive growth; “ \pm ” = weak growth; “-” = negative growth.

Cellulose as the sole carbon source $+0.1 \% \mathrm{NH}_{4} \mathrm{Cl}$ or casein as the sole carbon and nitrogen source.

${ }^{\dagger}$ Antibiotic activity of $T$. turnerae variants streaked on BMS or LB plates overlaid with BMS top-agar containing the tested Gram-negative (Sphingomonas sp. CS81 or Stenotrophomonas maltophilia) or Gram-positive (Bacillus cereus or Staphylococcus sciuri) bacteria. "+" = T. turnerae inhibits the tested bacterium; "“" = T. turnerae does not inhibit the tested bacterium.

See Materials and Methods for details. 
A)
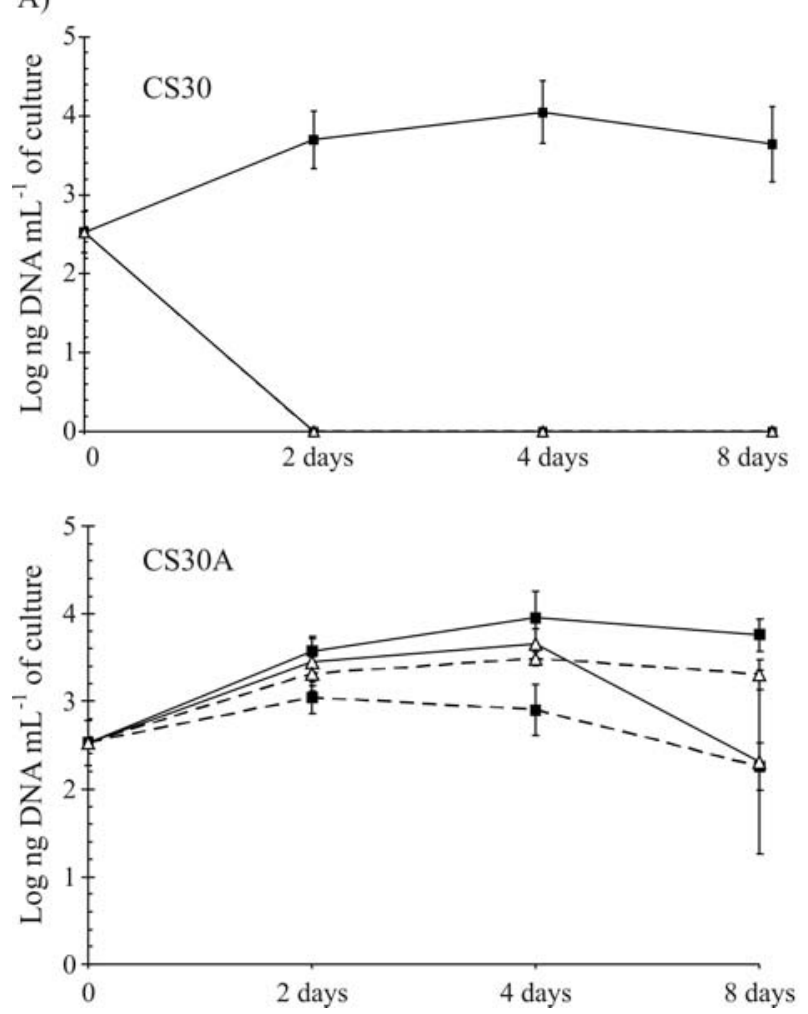

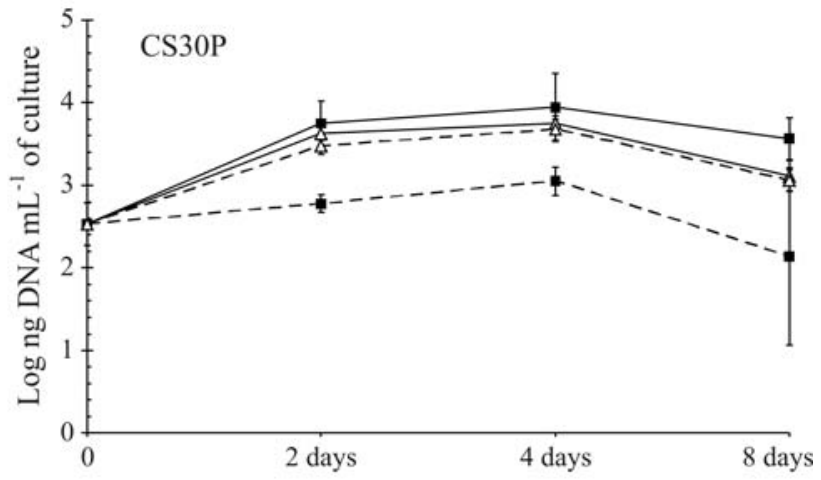

B)

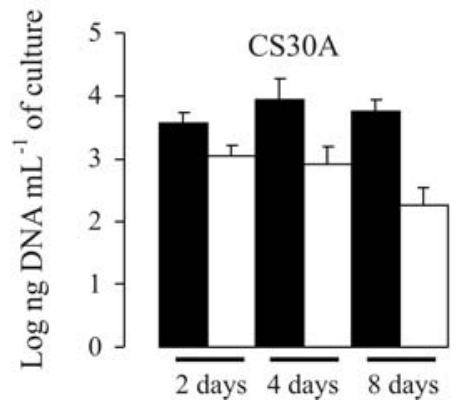

Figure 3 - Growth of T. turnerae in distinct media. (A) Growth kinetics of the T. turnerae original isolate CS30 and the variants CS30A and CS30P, when using cellulose (BMC medium; black squares) or casein (BMCa medium; white triangules) with $0.3 \mathrm{M} \mathrm{NaCl}$ (full lines) and in low salt media (dashed lines). *Growth is presented as the Log of the total DNA concentration ( $\mathrm{ng} \mathrm{ml}^{-1}$ of culture) after 2,4 and 8 days growth at $30^{\circ} \mathrm{C}$ and 115 rev min $^{-1}$. $* *$ See Materials and Methods for details; (B) Detail showing CS30A and CS30P growth profile, when using cellulose as the sole carbon source with $0.3 \mathrm{M} \mathrm{NaCl}$ (black) and in low salt media (white).

isolates from $N$. reynei gills (Figure 1). 16S rDNA sequencing showed that these two strains differ by a single base pair and are closely related to the T. turnerae type strain (Distel et al., 2002a, 2002b). CS30 and CS32 were isolated from distinct gills samples, although at present we do not know whether distinct symbiont ribotypes co-exist in the same individual $N$. reynei host, as was described for L. pedicellatus (Distel et al., 2002a; Luyten et al., 2006). However, the CS32 16S rDNA profile was not observed when using gill bulk DNA (data not shown), thereby indicating that this might be a less commonly represented symbiont in $N$. reynei.

Symbiont PCR screening of $N$. reynei gills, gonads, mantle, siphons and intestines strongly suggested that $T$. turnerae is strictly confined to the host's gills (Figure 2). Other eubacteria are present in $N$. reynei intestines, these possibly being associated with filtered particles, since there is no evidence indicating their role in host biology. No eubacteria were detected in mantle, siphon or gonad, thereby giving rise to pertinent questions regarding vertical transmition of symbionts in $N$. reynei.

In the present work, novel $T$. turnerae variants were spontaneously obtained in vitro, after challenging the CS30 strain to grow on a usually non-permissive medium with low-salt concentration and casein. It is known that some bacteria have developed clonal expansion strategies to face changing environments (Moxon et al., 1994), and enhancing the probability of survival (Oliver et al., 2000; Bayliss et al., 2001; Giraud et al., 2001). Clonal variants were also observed in other symbionts, such as the nematode $\gamma$-proteobacterium Photorhabdus luminescens, and were shown to be associated with major genomic variation, including re-arrangements in antibiotic biosynthetic genes (Gaudriault et al., 2008). Interestingly, T. turnerae variants presented distinct antibiotic activity (Table 1), although the molecular basis and stimulus to produce these variants are still unknown.

The identity of the purified variants CS30A and CS30P was confirmed as T. turnerae by $16 \mathrm{~S}$ rDNA analysis. They differ from the original isolate by the ability to grow on casein or to use cellulose when subjected to the reduced $\mathrm{Na}^{+}$and $\mathrm{Cl}^{-}$ion concentrations of the basal medium $(\sim 0.01$ to $0.04 \mathrm{M} \mathrm{NaCl})$. This allowed us to show that $\mathrm{NaCl}$ is important for optimal T. turnerae growth, when using cellulose as substrate (Figure 3, Table 1). This is in agreement with the maximum activity of $T$. turnerae cellulases under 0.2 to $0.4 \mathrm{M} \mathrm{NaCl}$ (Greene et al., 1988), and their increased binding activity to cellulose substrate when $0.5 \mathrm{M}$ $\mathrm{NaCl}$ was added (Imam et al., 1993). It was shown that the CS30A celA gene is expressed even without the addition of 
A)

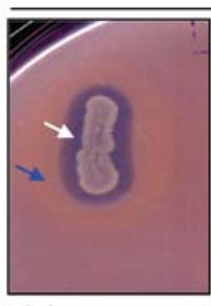

Sphingomonas

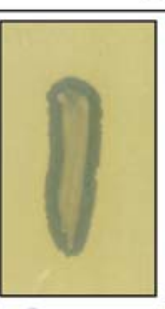

B. cereus
$\operatorname{CS} 30$

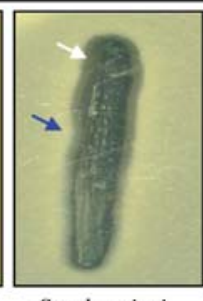

Staph. sciuri

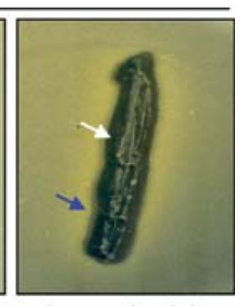

Sten. maltophilia

B)

BMS

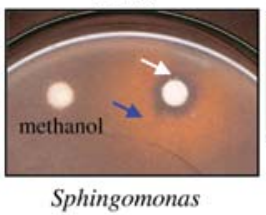

C)

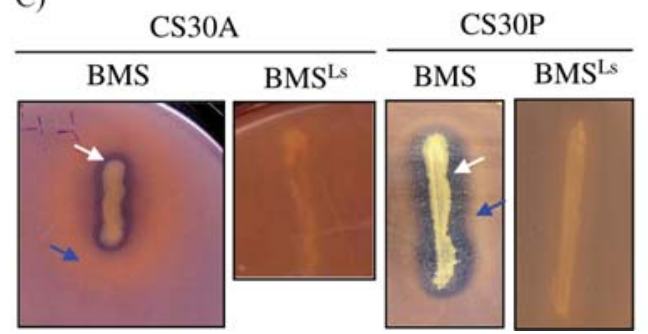

Figure 4 - T. turnerae activity on Sphingomonas sp. CS81, Stenotrophomonas maltophilia, Bacillus cereus and Staphylococcus sciuri growths. (A) Direct streak of T. turnerae CS30 on BMS top-agar inoculated with Sphingomonas sp., Stenotrophomonas maltophilia and the Gram-positive strains of Bacillus cereus and Staphylococcus sciuri; (B) Paper-discs with T. turnerae CS30 crude methanolic extracts on BMS or LB plates overlaid with Sphingomonas sp., Stenotrophomonas maltophilia and the Gram-positive strains of Bacillus cereus and Staphylococcus sciuri. A pure methanol control is presented on the Sphingomonas plate; (C) T. turnerae CS30A and CS30P streaked on sucrose media with $0.3 \mathrm{M} \mathrm{NaCl}(\mathrm{BMS})$ or low salt media $\left(\mathrm{BMS}^{\mathrm{Ls}}\right)$ overlaid with Sphingomonas sp. top-agar. White arrow: bacterial growth inhibition halo; Blue arrow: bacterial growth enhancement activity. *See Materials and Methods for details.

$\mathrm{NaCl}$. Nevertheless, further experiments should be carried out to determine the regulation of cellulase gene expression on various salt concentrations. Interestingly, certain Teredinidae, such as Psiloteredo healdi, can be found in freshwater (Distel, 2003; Santos et al., 2005). In this case, the intracellular environment in the host's gills may not be affected. Furthermore, there are no reports on the effects of symbiotic cellulase activity on host growth in fresh water.

The isolation of variants with low $\mathrm{NaCl}$ requirements contrasts with the original description of T. turnerae as being an obligate marine bacterium, with a higher need for $\mathrm{NaCl}$ (0.1 to 0.6 M) (Greene and Freer, 1986; Distel et al., 2002b). It is intriguing that, even though T. turnerae is able to grow in vitro in the absence of a host-cell partnership, a free-living form of this bacterium has never been observed in nature. We have been unsuccessful in attempts to isolate

T. turnerae, and by means of PCR, detect its celA gene in mangrove substrates, this including water, mud, decaying wood, submerged mangrove leaves and tree pneumatophores (data not shown). Previous attempts to isolate freeliving forms of $T$. turnerae have also failed (Waterbury et al., 1983). There is the possibility of spontaneous variants of T. turnerae arising in nature, which, through novel physiological skills might possibly be capable of colonizing a broad spectrum of aquatic habitats. It is possible that like traits in T. turnerae variants could support free-living bacterial populations subjected to the spatial/temporal physicochemical changes that occur in estuarine waters, where salinity varies from zero to over $35(\sim 0.6 \mathrm{M} \mathrm{NaCl})$.

The observed bactericidal activity could be advantageous for $T$. turnerae both in competiting with other bacteria if present as a free-living form in marine environments, or in playing a role in symbio. This seems to be a common feature of T. turnerae, since another strain isolated in our lab from the shipworm Lyrodus massa presented the same antibacterial activity (data not shown). In fact, Sphingomonas spp., Sten. maltophilia, the Gram-positive bacteria Bacillus spp. and Staphylococcus spp. are all present in marine environments and associated with invertebrates (Faghri et al., 1984; Cavicchioli et al., 1999; Furushita et al., 2005; Miao and Qian, 2005; Li et al., 2007; Romanenko et al., 2007, 2008; Muscholl-Silberhorn et al., 2008; Zhu et al., 2008). Sphingomonas sp. was the only tested bacterium inhibited in the same manner by both the original T. turnerae isolate as well as its variants, in an activity which is potentially unrelated to the inhibition of the other tested Gram-negative and Gram-positive bacteria. It is noteworthy that bacteria of the genus Sphingomonas present glycosphingolipids in the outer membrane which act as regulatory molecules (Olsen and Jantzen, 2001; Yabuuchi et al., 2002; Heung et al., 2006). Hence it is possible that the bioactive compounds produced by $T$. turnerae might, in turn, affect these molecules. This is being investigated. Moreover, it is conceivable that the systemic spread of bioactive compounds secreted by $T$. turnerae in symbio might be related to the popular therapeutic applications of $N$. reynei in the north of Brazil. Further attempts should focus on the characterization of these symbiotic bioactive compounds and the identification of their biosynthetic gene(s).

\section{Acknowledgments}

This work was supported in part by the Brazilian federal agency $\mathrm{CNPq}$ (Grant $\mathrm{MCT} / \mathrm{CNPq}$ 02/2006 n. 470967/2006-4) and FAPERJ. This is part of Amaro E. Trindade-Silva's $\mathrm{PhD}$ thesis and it was supported by the Brazilian fellowship programs $\mathrm{CNPq}$ and PDEE/CAPES through the Graduate Program at the Departamento de Genética (Instituto de Biologia, Universidade Federal do Rio de Janeiro). The authors would like to thank Dr. Hector Seuanez and Dr. Miguel A. M. Moreira (Instituto Nacional 
do Câncer/Divisão de Genética - Rio de Janeiro, Brazil) for the sequencing support. We would also like to thank the Laboratório de Virologia Molecular and Laboratório de Genética Molecular Vegetal (Dept. Genética, Inst. Biol., Universidade Federal do Rio de Janeiro) for material support, Dr. Shelby N. Freer (U.S. Department of Agriculture) for providing the Psiloteredo healdi celA gene sequence, Dr. Antônio R. Moreira (Department of Chemical and Biochemical Engineering, University of Maryland) for suggesting improvements in the composition of the basal medium, and Dr. Ana L. M. Giannini and Dr. Franklin D. Rumjanek (Universidade Federal do Rio de Janeiro) for constructive comments.

\section{References}

Ahuja SK, Ferreira GM and Moreira AR (2004) Production of an endoglucanase by the shipworm bacterium, Teredinobacter turnirae. J Ind Microbiol Biotechnol 31:41-47.

Andrade J (1979) Folclore na Região do Salgado, Pará. Teredos na Alimentação, Profíssões Ribeirinhas. Editorial Livramento, São Paulo, 94 pp.

Bayliss CD, Field D and Moxon ER (2001) The simple sequence contingency loci of Haemophilus influenzae and Neisseria meningitidis. J Clin Invest 107:657-662.

Busse HJ, Hauser E and Kämpfer P (2005) Description of two novel species, Sphingomonas abaci sp. nov. and Sphingomonas panni sp. nov. Int J Syst Evol Microbiol 55:2565-2569.

Carpenter EJ and Culliney JL (1975) Nitrogen fixation in marine shipworms. Science 187:551-552.

Cavicchioli R, Fegatella F, Ostrowski M, Eguchi M and Gottschal J (1999) Sphingomonads from marine environments. J Ind Microbiol Biotechnol 23:268-272.

DeMoraes DT and Lopes SGBC (2003) The functional morphology of Neoteredo reynei (Bartsch, 1920) (Bivalvia, Teredinidae). J Moll Stud 69:311-318.

Distel DL (2003) The biology of marine wood boring bivalves and their bacterial endosymbionts. In: Goodell B, Nicholas DD and Schultz TP (eds) Wood Deterioration and Preservation. V. 845. American Chemical Society Press, Washington DC, pp 253-271.

Distel DL, DeLong EF and Waterbury JB (1991) Phylogenetic characterization and in situ localization of the bacterial symbiont of shipworms (Teredinidae, Bivalvia) by using $16 \mathrm{~S}$ rRNA sequence analysis and oligodeoxynucleotide probe hybridization. Appl Environ Microbiol 57:2376-2382.

Distel DL, Beaudoin DJ and Morril W (2002a) Coexistence of multiple proteobacterial endosymbionts in the gills of the wood-boring bivalve Lyrodus pedicellatus (Bivalvia, Teredinidae). Appl Environ Microbiol 68:6292-6299.

Distel DL, Morril W, MacLaren-Toussaint N, Franks D and Waterbury J (2002b) Teredinibacter turnerae gen. nov., sp. nov., a dinitrogen-fixing, cellulolytic, endosymbiotic $\gamma$-Proteobacterium isolated from the gills of wood-boring molluscs (Bivalvia, Teredinidae). Int J Syst Evol Microbiol 52:2261-2269.

Faghri MA, Pennington CL, Cronholm LS and Atlas RM (1984) Bacteria associated with crabs from cold waters with em- phasis on the occurrence of potential human pathogens. Appl Environ Microbiol 47:1054-1061.

Ferreira GM, Ahuja SK, Sierks MR and Moreira AR (2001) Pleomorphism of the marine bacterium Teredinobacter turnirae. Lett Appl Microbiol 33:56-60.

Freer SN, Greene RV and Bothast RJ (2001) Gene structure of a bifunctional cellulase gene (celA) isolated from Teredinobacter turnerae. In: Himmel ME, Baker JO and Saddler JN (eds) Glycosyl Hydrolases for Biomass Conversion. V. 769. American Chemical Society Symposium Series, Washington DC, pp 39-54.

Furushita M, Okamoto A, Maeda T, Ohta M and Shiba T (2005) Isolation of multidrug-resistant Stenotrophomonas maltophilia from cultured Yellowtail (Seriola quinqueradiata) from a marine fish farm. Appl Environ Microbiol 71:5598-5600.

Gallager SM, Turner RD and Berg CJ (1981) Physiological aspects of wood consumption, growth and reproduction in the shipworm Lyrodus pedicelatus Quatrefages (Bivalvia, Teredinidae). J Exp Mar Biol Ecol 52:63-77.

Gaudriault S, Pages S, Lanois A, Laroui C, Teyssier C, JumasBilak E and Givaudan A (2008) Plastic architecture of bacterial genome revealed by comparative genomics of Photorhabdus variants. Genome Biol 9:R117.

Giraud A, Matic I, Tenaillon O, Clara A, Radman M, Fons M and Taddei F (2001) Costs and benefits of high mutation rates: Adaptative evolution of bacteria in the mouse gut. Science 291:2606-2608.

Greene RV and Freer SN (1986) Growth characteristics of a novel nitrogen-fixing cellulolytic bacterium. Appl Environ Microbiol 52:982-986.

Greene RV, Griffin HL and Freer SN (1988) Purification and characterization of an extracellular endoglucanase from the marine shipworm bacterium. Arch Biochem Biophys 267:334-341.

Greene RV, Cotta MA and Griffin HL (1989) A novel symbiotic bacterium isolated from marine shipworm secretes proteolytic activity. Curr Microbiol 19:353-356.

Griffin HL, Greene RV and Cotta MA (1992) Isolation and characterization of an alkaline protease from the marine shipworm bacterium. Curr Microbiol 24:111-117.

Heung LJ, Luberto C and Del Poeta M (2006) Role of sphingolipids in microbial pathogenesis. Infect Immun 74:28-39.

Imam SH, Greene RV and Griffin HL (1993) Binding of extracellular carboxymethylcellulase activity from the marine shipworm bacterium to insoluble cellulosic substrates. Appl Environ Microbiol 59:1259-1263.

Kreger van Rij NJW (1984) The Yeasts: A Taxonomic Study. $3^{\text {rd }}$ edition. Elsevier Science Publ, Amsterdam, 1082 pp.

Lane DJ (1991) 16S/23S rRNA sequencing. In: Stackebrandt E and Goodfellow M (eds) Nucleic Acid Techniques in Bacterial Systematics. Wiley \& Sons, Chichester, pp 115-175.

Lechene CP, Luyten Y, McMahon G and Distel DL (2007) Quantitative imaging of nitrogen fixation by individual bacteria within animal cells. Science 317:1563-1566.

Li ZY, Hu Y, Huang YQ and Huang Y (2007) Isolation and phylogenetic analysis of the biologically active bacteria associated with three south China sea sponges. Microbiology 76:494-499. 
Lim GE and Haygood MG (2004) "Candidatus Endobugula glebosa", a specific bacterial symbiont of the marine bryozoan Bugula simplex. Appl Environ Microbiol 70:4921-4929.

Luyten YA, Thompson JR, Morrill W, Polz MF and Distel DL (2006) Extensive variation in intracellular symbiont community composition among members of a single population of the wood-boring bivalve Lyrodus pedicellatus (Bivalvia, Teredinidae). Appl Environ Microbiol 72:412-417.

Medlin L, Elwood HJ, Stickel S and Sogin ML (1988) The characterization of enzimatically amplified eukaryotic 16S-like rRNA-coding regions. Gene 71:491-499.

Miao L and Qian PY (2005) Antagonistic antimicrobial activity of marine fungi and bacteria isolated from marine biofilm and seawaters of Hong Kong. Aquat Micob Ecol 38:231-238.

Moxon ER, Rainey PB, Nowak MA and Lenski RE (1994) Adaptative evolution of highly mutable loci in pathogenic bacteria. Curr Biol 4:24-33.

Muscholl-Silberhorn A, Thiel V and Imhoff JF (2008) Abundance and bioactivity of cultured sponge-associated bacteria from the Mediterranean Sea. Microb Ecol 55:94-106.

Neefs JM, Van de Peer Y, De Rijk P, Chapelle S and De Wachter R (1993) Compilation of small ribosomal subunit RNA structures. Nucleic Acids Res 21:3025-3049.

Oliver A, Cantón R, Campo P, Baquero F and Blázquéz J (2000) High frequency of hypermutable Pseudomonas aeruginosa in cystic fibrosis lung infection. Science 288:1251-1253.

Olsen I and Jantzen E (2001) Sphingolipids in bacteria and fungi. Anaerobe 7:103-112.

Piel J (2004) Metabolites from symbiotic bacteria. Nat Prod Rep 21:519-538.

Romanenko LA, Uchino M, Frolova GM, Tanaka N, Kalinovskaya NI, Latyshev N and Mikhailov VV (2007) Sphingomonas molluscorum sp. nov., a novel marine isolate with antimicrobial activity. Int $\mathrm{J}$ Syst Evol Microbiol 57:358-363.

Romanenko LA, Uchino M, Tanaka N, Frolova GM, Slinkina NN and Mikhailov VV (2008) Occurrence and antagonistic potential of Stenotrophomonas strains isolated from deep-sea invertebrates. Arch Microbiol 189:337-344.

Santos SML, Tagliaro CH, Beasley CR, Schneider H, Sampaio I, Filho CS and Muller ACP (2005) Taxonomic implications of molecular studies on northern Brazilian Teredinidae (Mollusca, Bivalvia) specimens. Genet Mol Biol 28:175179.

Silhavy TJ, Berman ML and Enquist LW (1984) Experiments with Gene Fusions. Cold Spring Harbor Laboratory Press, New York, pp 137-139.

Sipe AR, Wilbur AE and Cary SC (2000) Bacterial symbiont transmission in the wood-boring shipworm Bankia setacea (Bivalvia, Teredinidae). Appl Environ Microbiol 66:16851691.
Surette MG and Bassler BL (1998) Quorum sensing in Escherichia coli and Salmonella typhimurium. Proc Natl Acad Sci USA 95:7046-7050.

Teather RM and Wood PJ (1982) Use of Congo Red-polysaccharide interactions in enumeration and characterization of cellulolytic bacteria from the bovine rumen. Appl Environ Microbiol 43:777-780.

Throup J, Winson MK, Bainton NJ, Bycroft BW, Williams P and Stewart GSAB (1995) Signalling in bacteria beyond bioluminescence. In: Campbell A, Kricka L and Stanley P (eds) Bioluminescence and Chemiluminescence: Fundamentals and Applied Aspects. Wiley \& Sons, Chichester, pp 89-92.

Trytek RE and Allen WV (1980) Synthesis of essential amino acids by bacterial symbionts in the gills of the shipworm Bankia setacea (Tryon). Comp Biochem Physiol 67A:419427.

Turner RD (1966) A Survey and Illustrated Catalogue of the Teredinidae (Mollusca, Bivalvia). Harvard University Press, Cambridge, 265 pp.

Van de Peer Y, Chapelle S and De Wachter R (1996a) A quantitative map of nucleotide substitution rates in bacterial rRNA. Nucleic Acids Res 24:3381-3391.

Van de Peer Y, Nicolaï S, De Rijk P and De Wachter R (1996b) Database on the structure of small ribosomal subunit RNA. Nucleic Acids Res 24:86-91.

Waterbury JB, Calloway CB and Turner RD (1983) A cellulolytic nitrogen-fixing bacterium cultured from the gland of Deshayes in shipworms (Bivalvia, Teredinidae). Science 221:1401-1403.

$\mathrm{Xu}$ PN and Distel DL (2004) Purification and characterization of an endo-1, 4- $\beta$-D glucanase from the cellulolytic system of the wood-boring marine mollusk Lyrodus pedicellatus (Bivalvia, Teredinidae). Mar Biol 144:947-953.

Yabuuchi E, Kosako Y, Fujiwara N, Naka T, Matsunaga I, Ogura $\mathrm{H}$ and Kobayashi K (2002) Emendation of the genus Sphingomonas Yabuuchi et al. 1990 and junior objective synonymy of the species of three genera, Sphingobium, Novosphingobium and Sphingopyxis, in conjunction with Blastomonas ursincola. Int J Syst Evol Microbiol 52:14851496.

Zhu P, Li Q and Wang G (2008) Unique microbial signatures of the alien hawaiian marine sponge Suberites zeteki. Microb Ecol 55:406-414.

\section{Internet Resources}

BlastN, http://www.ncbi.nlm.nih.gov.

Associate Editor: Luís Carlos de Souza Ferreira

License information: This is an open-access article distributed under the terms of the Creative Commons Attribution License, which permits unrestricted use, distribution, and reproduction in any medium, provided the original work is properly cited. 